Brazilian Journal

of Chemical

ISSN 0104-6632

Engineering

Printed in Brazil

Vol. 19, No. 02, pp. 167 - 173, April - June 2002

\title{
USE OF TOWER REACTORS FOR CONTINUOUS ETHANOL PRODUCTION
}

\author{
M.C.Viegas $^{1}{ }^{*}$, S.R.Andrietta ${ }^{2}$ and M.G.S.Andrietta ${ }^{2}$ \\ ${ }^{1}$ Faculdade de Engenharia Química, UNICAMP, ${ }^{2}$ CPQBA, UNICAMP, \\ Cx. P. 6171 CEP 13083-910, Campinas - SP, Brasil, \\ E-mail: viegas@cpqba.unicamp.br
}

(Received: February 10, 2002 ; Accepted: May 1, 2002)

\begin{abstract}
The purpose of this work was to develop a continuous fermentation system operating with a tower reactor using some flocculent yeast strains isolated from an industrial process. The strain was an used in the trial of the proposed system, composed of two serial glass tower reactor. The effects of the following variables were studied on the yield and productivity of the system: total reducing sugar (TRS), concentration in feeding, recycle flow in the second reactor, residence time and diameter/height ratio of the reactors. It was observed that the TRS concentration in feeding and residence time is the variables that interfere most with the productivity of the system. Yield was not affected by any of the variables within the range of values studied. All trials were performed according to a factorial experimental design (making up a total of 19 trials) and the results were evaluated by response surface.

Keywords: continuous fermentation, glass tower reactor.
\end{abstract}

\section{INTRODUCTION}

Alternative processes for minimizing ethanol production costs have been the topic of study of several research groups. The goal is to research the elimination of the separating centrifuges, because of their high installation and maintenance costs. One alternative has been the use of decanters to separate the cells. Projects installed at some industrial plants have shown these inadequate results. The failures of these systems are due not only to their slow dynamics, but also to the unfavorable conditions under which the yeast is exposed (high ethanol concentration and low substratum concentration) and the inappropriate design of the reactors.

Pilot studies on continuous fermentation with flocculent yeast began in the $80 \mathrm{~s}$. The goal of these processes was to work with a microorganism whose flocculent characteristics allowed elimination of the centrifuge stage, required to separate the cells from the fermented wine, since this stage was costly. These processes may achieve high productivity of about $18 \mathrm{~mL}$ of ethanol per $\mathrm{L}$ of reactor per hour, whereas continuous processes with centrifugation of optimized cells achieve $12 \mathrm{~mL}$ ethanol per $\mathrm{L}$ of reactor per $h$. This may be due to the fact that when working with fluidized bed reactors it is possible to operate the process with a high concentration of cells inside a $(45 \% \mathrm{v} / \mathrm{v})$, in addition to the fact that the do not require consecutive operations to separate the cells from the fermented wine. In continuous reactors with centrifugation of cells, it would not be economically advantageous to work with such high concentrations of cells, since a large number of centrifuges would be required for separation, making the process economically unviable due to high cost and periodical maintenance requirements, in addition to the consumption of a considerable amount of energy. In spite of the good results obtained, optimization studies of the industrial process are still required, since it has not been possible to operate under fermentation conditions that allow total elimination of the centrifugation stage for separation of cells.

*To whom correspondence should be addressed 
The advantages of fluidized bed bioreactors can be observed in many studies. Prince \& Barford (1982) stress that the configuration of these reactors may also represent an advance in the control of microbiological contamination, since bacteria present at the beginning of the process were quickly eliminated from the system when contaminants were 'washed out' of the reactor. Another advantage mentioned is the high concentration of yeast cells that accumulated in the reactor, making the system appropriate to operate at high productivities. According to Gòda \& Solá, (1995), the liquid flow in the fluidized bed bioreactor may be close to the plug flow, depending on the operation conditions used. This may be deemed a great advantage especially for reactions inhibited by the product, such as in the case of alcoholic fermentation. The high productivity and stability of the reactor are another positive point to be considered when working with fluidized bed reactors. When working with flocculent yeast for alcohol production in continuous systems with cell recycling, Bu'lock (1983) obtained a substratum conversion higher than $95 \%$ in a stable system for a long period in a tower bioreactor with cell recycling at a constant dilution rate of $0.20 \mathrm{~h}$. Paiva et al. (1996) achieved a maximum productivity of $18 \mathrm{~g}$ $\mathrm{EtOH} / \mathrm{L}$. h. Despite the wide availability of work on fluidized bed reactors, few studies can be found on the application of scale up methods. Rottenbacher et al. (1987) propose a model for this study of ethanol production, based on two parameters, residence time and the specific substratum supply.

The purpose of this work was to develop a continuous fermentation system operating with a tower reactor using self-immobilized yeast strains isolated from an industrial process (Distillery Diana, 95/96 harvest season), allowing accumulation of cells inside, there by eliminating the need for a separation unit. The system tests were performed in two $(5.8 \mathrm{~cm}$ diameter and $78 \mathrm{~cm}$ high) serial glass tower reactors simulating operation of an industrial plant, since this operation strategy favors alcoholic fermentation kinetics because fermentation product inhibition in less favorable than single reactor. Another advantage of the proposed system is the fact that it is not equipped with any consecutive separation stage.

\section{MATERIAL AND METHODS}

\section{Strain}

The Saccharomyces $s p$ yeast strain used in the system was isolated from the industrial fermentation unit at Distillery Diana during the 95/96 harvest season and selected from among fifteen total with strong flocculent characteristics. It was selected primarily for its flocculation capacity (Viegas, 1999), since this is the main characteristic required for maintaining the strain immobilized in the reactor.

\section{Inoculum}

The inoculum used to start the system was prepared in $250 \mathrm{~mL}$ Erlenmeyer flasks with $100 \mathrm{~mL}$ of sterilized medium $\left(15\right.$ minutes $\left.121^{\circ} \mathrm{C}\right)$ composed of $150 \mathrm{~g} / \mathrm{L}$ sucrose, $5.0 \mathrm{~g} / \mathrm{L}$ potassium diphosphate, $5.0 \mathrm{~g} / \mathrm{L}$ ammonium chloride, $1.0 \mathrm{~g} / \mathrm{L}$ heptahydrated magnesium sulfate, $1.0 \mathrm{~g} / \mathrm{L}$ potassium chloride and $6.0 \mathrm{~g} / \mathrm{L}$ yeast extract. The yeast grown in PDA (potato pextrose agar) slants for $24 \mathrm{~h}$ at $32^{\circ} \mathrm{C}$ was resuspended in sterilized water and inoculated at a $10 \%$ concentration of the total volume of the fermentative medium. The flasks were incubated in a shaker for $24 \mathrm{~h}$ at $32^{\circ} \mathrm{C}$ and $150 \mathrm{rpm}$. The fermented was fed to the fermentation system through a peristaltic bomb.

\section{Feed Substratum}

The substratum used to feed the pilot system was a synthetic medium using sucrose as a carbon source (with varied concentration in the trials performed) added to $5.0 \mathrm{~g} / \mathrm{L}$ potassium diphosphate, $5.0 \mathrm{~g} / \mathrm{L}$ ammonium chloride, $1.0 \mathrm{~g} / \mathrm{L}$ heptahydrated magnesium sulfate, $1.0 \mathrm{~g} / \mathrm{L}$ potassium chloride and $6.0 \mathrm{~g} / \mathrm{L}$ yeast extract. The medium was prepared in $10 \mathrm{~L}$ glass flasks and sterilized in an autoclave at $121^{\circ} \mathrm{C}$ for 30 minutes.

\section{Description of the Reactors}

The two 2.2-liter capacity bench reactors used were constructed using a design based on industrial experiences and basic engineering principles (Figure 1). They were built of $(5.8 \mathrm{~cm}$ diameter and $78 \mathrm{~cm}$ high) tower-shaped glass and equipped with a shirt for temperature control. Reactor temperature was kept constant with $32^{\circ} \mathrm{C}$ water circulating through the shirt. The substratum was fed in with a peristaltic bomb connected directly to the flasks containing the sterilized substratum. The substratum was fed through the rear of the reactor and the wine taken from the top. The addition of other components (antifoaming, antibiotic, etc.) was done manually at the top, when needed. The reactors also have an exit through the top for $\mathrm{CO}_{2}$ exhaust and sample extraction. 


\section{Operation of the Reactor}

After inoculation in the first reactor, an initial stage retention and accumulation of yeast cells was carried out. This was achieved by continuously feeding the reactor with a sterilized medium with a $125-\mathrm{g} / \mathrm{L}$-substratum concentration for six days, until a constant and satisfactory concentration of cells to operate the process was obtained. After the accumulation stage, nineteen trials were carried out according to the randomly factorial experimental design with three repetitions at the central point to determine experimental error. The variables studied were $\mathrm{S}(100$ to $150 \mathrm{~g} / \mathrm{L})$ - concentration of feed substratum; tr $(5$ to $10 \mathrm{~h})$ - residence time; Q (28.6 to $85.8 \mathrm{~mL} / \mathrm{min})$ - fermented medium recycle flow in the second reactor and $\mathrm{D} / \mathrm{h}(0.0892$ to 0.116 ) - diameter/height ratio. Fermentation was monitored by periodically taking samples from both the first and second reactors, and the following factors were determined for each one: (a) concentration of cells in the effluent and (b) concentration of TRS and ethanol in the fermented medium. The stationary state was reached before the beginning of a new trial.

To optimize the system of reactors, a factorial design with four independent variables was performed with the following as the response variables: (a) yield $(\%)$ and $(b)$ productivity $\quad(\mathrm{mL} \mathrm{EtOH} / \mathrm{L}$ per h) of the fermentation system, respectively calculated using equations 1 and 2 . Therefore, $2^{4}$ (16) trials were carried out to obtain a first order model and three trials were conducted at the central point to estimate experimental error. To obtain the first order model of the system in question, the -1.0 and +1.0 levels were included.

$$
\text { Yield }=\frac{\left[\text { Ethanol }\left({ }^{\circ} \mathrm{GL}\right)\right] \cdot 1000}{[\text { TRS input }(\mathrm{g} / \mathrm{L})] \cdot 0 \cdot 6475}
$$

where 0.6475 corresponds to the stoichiometric factor.

$$
\text { Prod }=\mathrm{D} *\left[\text { Ethanol }\left({ }^{\circ} \mathrm{GL}\right)\right] \cdot 10
$$

Table 1 shows the conditions under which each trial was performed.

With the yield and productivity results for each trial, the Statistics 5.0 Program was used to obtain the effects of the variables, the regression coefficients of the first order model, the analysis of model variance and the response surfaces through which the system was optimized.

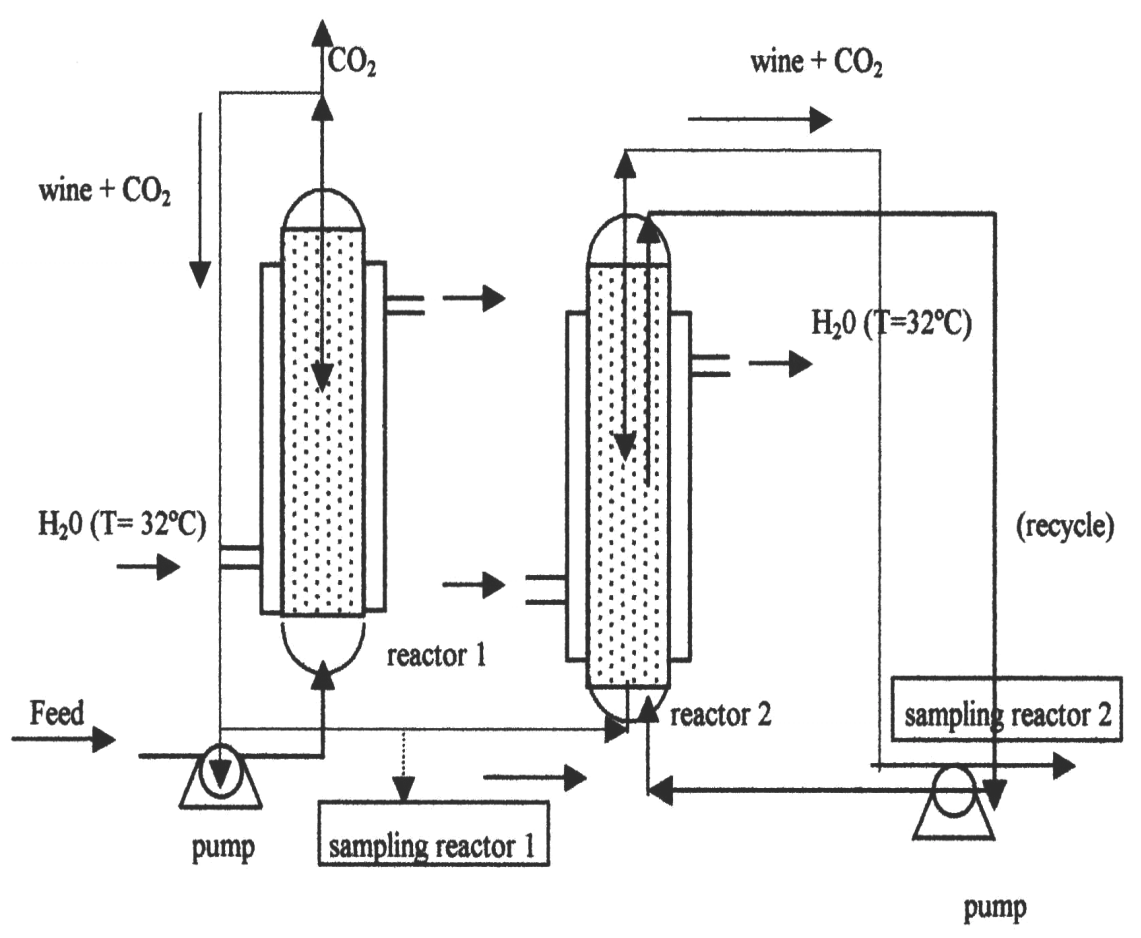

Figure 1: Bench reactor diagram. 
Table1: Trials performed using the linear factorial design, where $\mathrm{S}$ is Substratum concentration (g/L); tr is residence time $(\mathrm{h}) ; \mathrm{Q}$ is recycle flow $(\mathrm{mL} / \mathrm{min}) ; \mathrm{D} / \mathrm{h}$ is diameter/height ratio in the reactor; Prod is productivity ( $\mathrm{mL} \mathrm{EtOH/L.} \mathrm{h.)} \mathrm{Yield} \mathrm{is} \mathrm{showing} \mathrm{in} \mathrm{\% .}$

\begin{tabular}{|c|c|c|c|c|c|}
\hline $\mathbf{S}$ & tr & $\mathbf{Q}$ & $\mathbf{D} / \mathbf{h}$ & Prod. & Yield \\
\hline 100.00 & 5.00 & 28.60 & 0.09 & 13.26 & 95.40 \\
150.00 & 5.00 & 28.60 & 0.09 & 19.44 & 92.13 \\
100.00 & 5.00 & 28.60 & 0.12 & 12.55 & 91.80 \\
150.00 & 5.00 & 28.60 & 0.12 & 19.29 & 92.97 \\
100.00 & 5.00 & 85.80 & 0.09 & 13.86 & 96.92 \\
150.00 & 5.00 & 85.80 & 0.09 & 17.61 & 87.00 \\
100.00 & 5.00 & 85.80 & 0.12 & 14.04 & 95.87 \\
150.00 & 5.00 & 85.80 & 0.12 & 19.02 & 92.24 \\
100.00 & 10.00 & 28.60 & 0.09 & 6.40 & 95.52 \\
150.00 & 10.00 & 28.60 & 0.09 & 9.49 & 92.56 \\
100.00 & 10.00 & 28.60 & 0.12 & 7.24 & 94.96 \\
150.00 & 10.00 & 28.60 & 0.12 & 9.96 & 94.99 \\
100.00 & 10.00 & 85.80 & 0.09 & 6.54 & 94.12 \\
150.00 & 10.00 & 85.80 & 0.09 & 9.90 & 92.75 \\
100.00 & 10.00 & 85.80 & 0.12 & 6.30 & 94.16 \\
150.00 & 10.00 & 85.80 & 0.12 & 10.20 & 94.44 \\
125.00 & 7.50 & 57.20 & 0.10 & 10.66 & 94.22 \\
125.00 & 7.50 & 57.20 & 0.10 & 10.39 & 96.83 \\
125.00 & 7.50 & 57.20 & 0.10 & 10.55 & 95.80 \\
\hline
\end{tabular}

\section{Analytic Methods}

\section{(a) Determination of the Ethanol Produced}

Samples of the fermented wine were initially submitted to distillation in a microdistiller for elimination of the impurities interfering with the analysis. The material obtained was treated with phosphate dichromate in an acid medium. The ethanol was oxidized in acetic acid with reduction of the phosphate dichromate Andrietta et al. (1995).

\section{(b)Determination of the Cellular Mass Produced}

The determination was made by withdrawing 10 $\mathrm{mL}$ aliquots from the fermented medium. The sample was then centrifuged at $4000 \mathrm{rpm}$ for 5 minutes. The precipitate was resuspended in distilled water and centrifuged again. This operation was repeated three times (for a complete wash of the cells). The centrifuged material was transferred to a previously tared plate and put in a heater at $80^{\circ} \mathrm{C}$ until constant weight was reached. The value was from the initial weight difference of the plate (Andrietta et al., 1995).

\section{(c) Determination of the Cellular Concentration Inside the Fermentors}

The determination was performed by measuring the height of the bed formed in each of the reactors and calculating the volume of each of the beds formed once the diameter $(\mathrm{d}=5.8 \mathrm{~cm})$ was known. A $10 \mathrm{~mL}$ aliquot from the fermented medium was withdrawn from inside each bed and centrifuged at $4000 \mathrm{rpm} / 5$ minutes. After being washed three times in distilled water, the precipitate was transferred to the previously tared plate and put in the heater at $80^{\circ} \mathrm{C}$ until constant weight was reached. The dry mass concentration $(\mathrm{g} / \mathrm{L})$ was obtained from the difference between the initial and final weights of the plate divided by the aliquot volume. The total dry mass ( $\mathrm{g}$ ) was obtained by multiplying the dry mass concentration by the total volume of the bed. To determine the total volume of the concentration dry mass in the reactor $(\mathrm{g} / \mathrm{L})$, it was assumed that the cells were uniformly distributed inside, obtained by 
the division of the total dry mass ( $g$ ) by the total volume of the reactor.

\section{Determination of Total Reducing Sugars (TRS)}

The dinitrosalicylic acid method (DNS) was used to determine the TRS (Miller, 1959).

\section{RESULTS AND DISCUSSIONS}

Table 1 shows the results of the optimization tests in reactors using the factorial experimental design and response surface analysis.

The average cell concentration in reactors 1 and 2 was $46.60 \mathrm{~g} / \mathrm{L}$ and $45.00 \mathrm{~g} / \mathrm{L}$, respectively, with small variations for each trial.

Based on the results in Table 1, the effects of the independent variables on yield and productivity were studied.

\section{Yield}

In Table 1 it can be observed that the variables in the established range studied do not interfer with the yield values. The Statistics 5.0 Program shows that none of the terms is statistically significant in the $95 \%$ confidence interval.

\section{Productivity}

Optimization of productivity followed the study of the effects of the variables on yield. The same sequence of trials as that shown in Table 1 was used for the factorial design. The Statistics 5.0 Program shows that the most significant effects in the $95 \%$ confidence interval are residence time and substratum concentration in feeding.

The final actual model relating productivity and substratum concentration in feeding, residence time, recycle flow and diameter/height ratio was obtained after the most significant variables were determined, and it is mathematically described in a first order equation by equation 3 :

$$
\begin{aligned}
& \text { Prod. }=2.33+0.16 . \mathrm{S}-0.22 . \mathrm{tr}-0.04 . \mathrm{Q} \\
& -0.01 . \mathrm{S} . \mathrm{tr}+0.35 . \mathrm{D} / \mathrm{h} . \mathrm{Q}
\end{aligned}
$$

To verify whether the model explains a significant amount of variation in the experimental data, the F significance test was used. Thus, the estimated $F$ value, based on the (91.03) experimental data was compared, with the table value for an $\mathrm{F}_{5.13}$
(3.03) reference frequency distribution Bruns et al. (1995). Since the F table value for the $95 \%$ confidence interval was thirty times lower than the value obtained with the model, it is possible to state that the amount of variation due to the model is significantly higher than the unexplained variation, thereby attesting to the validity of the experimental model obtained.

Hence, if the model obtained (equation 3) is valid, it is possible to generate contour curves (Figure 2) that will be analyzed to define the optimum operation band for the optimization of process productivity.

In order to define the optimum operation band, both yield and productivity should be considered i.e, the highest productivity possible should be obtained without affecting the yield value.

Table 1 shows that yield was not affected by the changes in independent variables in the band studied, but the same cannot be said for productivity, since it has shown large variations within the band (Figure 2). In Figure 2, it is possible to observe that productivity tends mostly towards high substratum concentrations in feeding and low residence time, making it possible to operate with productivities of up to $19.45 \mathrm{~mL} \mathrm{EtOH} / \mathrm{L} . \mathrm{h}$ (15.40 g EtOH/L.h) with $92.13 \%$ yields and a $9.8 \% \mathrm{v} / \mathrm{v}$ ethanol concentration in the wine. Even though the highest productivity value has not been reached, these results show quite significant gains when compared to conventional fermentation processes for ethanol production. According to Andrietta and Maugeri (1994), a conventional continuous fermentation unit using separating centrifuges and nonflocculent yeast cells may operate with an ethanol concentration between 8.0 and $9.0 \% \mathrm{v} / \mathrm{v}$, a $87 \%$ yield and a $7.9 \mathrm{~g} \mathrm{EtOH} / \mathrm{L} . \mathrm{h}$ productivity when molasses is used as the raw material.

Another relevant point in the proposed system is the volume decrease in the cell bed in the first reactor when high substratum feeding rates are applied. This fact results from the large amount of $\mathrm{CO}_{2}$ released by unit of time occurring under these conditions. In spite of initial decrease in productivity, this $\mathrm{CO}_{2}$ release may eventually result in a drop in the fermentation yield. Attention should be given to adopting operational conditions that can result in productivity values higher than the ones obtained in the band studied, thus avoiding operational destabilization of the system.

Using this system may result in gains in productivity and production cost due to the elimination of the need to use the separating centrifuges and the acid treatment system, which 
together correspond to approximately $25 \%$ of the industrial processing costs. The proposed system also has a better performance than the those developed by Paiva et al. (1996), whose work with flocculent yeast in tower reactors with cell separation for recycling by decantation obtained values of 14.4 to $17.3 \mathrm{~g} \mathrm{EtOH} / \mathrm{L}$. h for productivity and $88.3 \%$ to $82.6 \%$ for yield with a fixed residence time of 5 hours and substratum concentration in the range of 160 to $200 \mathrm{~g} / \mathrm{L}$.

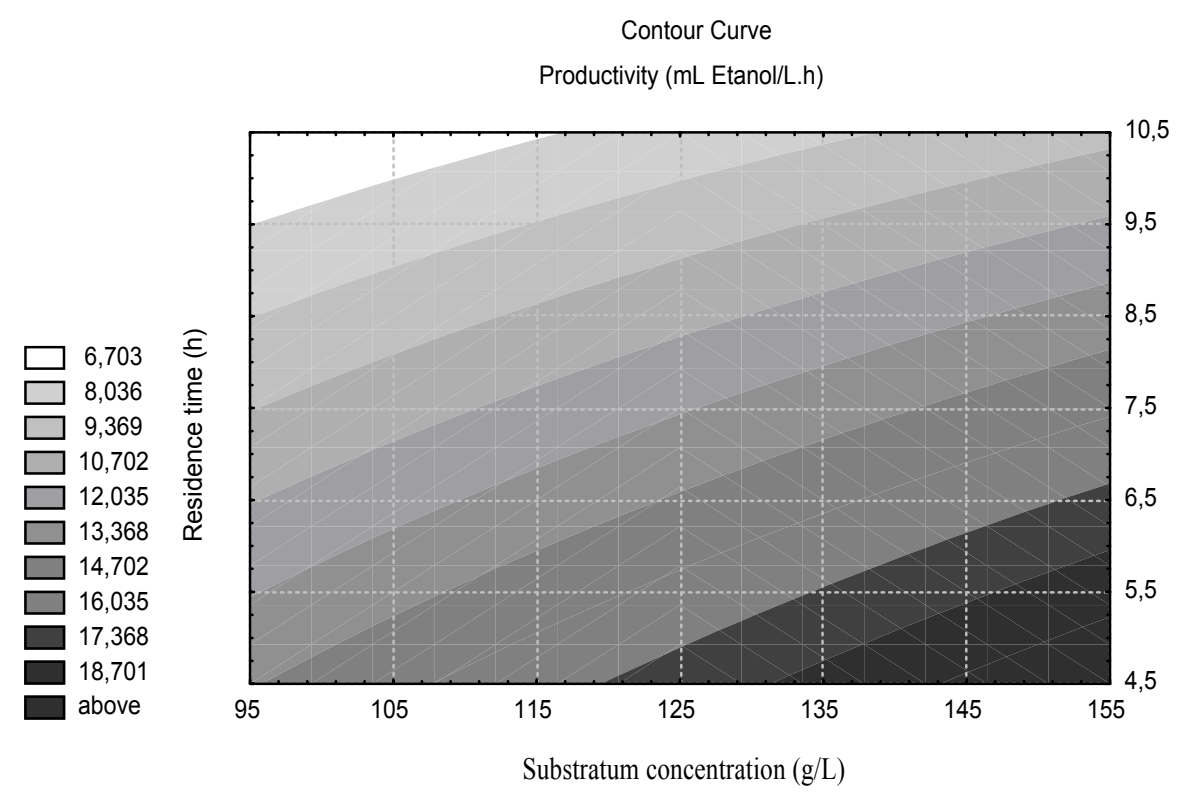

Figure 2: Contour curves for obtaining the optimum operation band.

\section{CONCLUSIONS}

a) Of the variables studied, only substratum concentration in feeding and residence time significantly influenced the productivity of the system.

b) Yield was not affected by any of the variables studied within the value bands evaluated.

c) It is possible to operate using tower reactors with flocculent yeast with no need for a cell recycling unit.

d) It is possible to obtain productivities starting at $15.40 \mathrm{~g} \mathrm{EtOH} / \mathrm{L}$. h with (93\%) satisfactory yield values with the serial tower reactors system.

\section{ACKNOWLEDGEMENT}

We acknowledge the financial support provided by FAPESP (Science Research Foundation of São Paulo, Brazil) for this work.

\section{NOMENCLATURE}

D Dilution rate $\left(\mathrm{h}^{-1}\right)$
$\begin{array}{ll}\mathrm{D} / \mathrm{h} & \text { Diameter/height ratio } \\ \mathrm{S} & \text { Concentration of feed substratum }(\mathrm{g} / \mathrm{l}) \\ \mathrm{Tr} & \text { Residence time }(\mathrm{h})\end{array}$

\section{REFERENCES}

Andrietta, S.R., Andrietta, M.G.S. and Rodrigues, M.I. Método de caracterização de leveduras de processo utilizando parâmetros cinéticos e produção específica. STAB Açúcar, Álcool e Subprodutos, vol. 13, no .4, pp. 22-25 (1995).

Andrietta, S.R. and Maugeri Filho, F. Optimum Design of a Continuous Fermentation Unit of an Industrial Plant Alcohol Production. Advances in Bioprocess Engineering, 1, pp. 47-52 (1994).

Bruns, R.E., Scarminio, I.S. and Neto, B.B. Planejamento e Otimização de Experimentos, Campinas: Editora da Unicamp (1995), 299 pp.

Bu'lock, J.D. Practical Advantages of Very Flocculent Yeast for Alcohol Production in Single and Multiple Continuous Systems. Int. Spec. Symp. Yeast. England, vol. 8, A .186 (1983).

Gòdia, F. and Solá, C. Fluidized-Bed Bioreactors. Biotechnology Progress, Barcelona, vol. 11, no. 5, pp. 479-497 (1995). 
Mller, G.L. Use of Dynitrosalicylic Acid Reagent for Determination of Reducing Sugar. Analytical Chem., vol. 31, pp. 426-428 (1959).

Paiva, T.C.B., Sato, S., Visconti, A.E.S. and Castro, L.A.B. Continuous Alcoholic Fermentation Process in a Tower with Recycling of Flocculating Yeast. Applied Biochemistry and Biotechnology. vol. 57, no. 58, pp. 535-541 (1996).

Prince, I.G. and Barford, J.P. Continuous Tower Fermentation for Power Ethanol Production. Biotechnology Letters. _vol.4, no. 4, pp. 263-268
(1982).

Rottenbacker, L., Schossler, M. and BAUER, W. Modeling of Solid-State Fluidized Bed Fermenter for Ethanol Production with $S$. cerevisae. Bioprocess Eng. vol. 2, pp. 25-31 (1987).

Viegas, M.C. Desenvolvimento de um reator de bancada de leito fluidizado para produção de etanol utilizando linhagens de leveduras floculantes. Campinas: FEQ, UNICAMP Master's, Faculdade de Engenharia Química, Universidade Estadual de Campinas (1999). 